\title{
Iconic Product Advantage for Improving Marketing Performance of Indonesian Small and Medium Enterprises
}

Submitted $11 / 11 / 19,1^{\text {st }}$ revision $20 / 12 / 20,2^{\text {nd }}$ revision 13/01/20, accepted 30/01/20

\author{
Ahmad Hanfan ${ }^{1}$, Hayati Nupus ${ }^{2}$, Lutfi $^{3}$
}

\begin{abstract}
:
Purpose: To examine the role of iconic product advantage to improve marketing performance.

Design/Methodology/Approach: This study uses primary data obtained from interviews based on a list of questions to 103 respondents of Salted Egg SMEs in Brebes Regency, Central Java Province, Indonesia.

Findings: All hypotheses are accepted, market orientation influences iconic product advantage, product innovation influences iconic product advantage, dynamic capability influences iconic product advantage, iconic product advantage influences marketing performance.

Practical Implications: There is no research that examines the market orientation of marketing performance that is bridged by the iconic product advantage. This research proves that the iconic product advantage bridges the market orientation with the marketing performance of Brebes Salted Egg SMEs that is supported by product innovation and dynamic capability.

Originality/Value: Iconic product advantage is novelty in this study. Iconic product advantage is the superiority of the company by making products that become icons or symbols that serve as a reminder for consumers with the symbols contained in the product.
\end{abstract}

Keywords: Product innovation, dynamic capability, iconic product advantage, marketing performance, Brebes salted egg SMEs.

JEL codes: M30, M31.

Article Type: Research study.

\footnotetext{
${ }^{1}$ Lecturer in the Faculty of Economics and Business, and lecturer in Master of Management at Pancasakti University, ahmadhanfan@yahoo.com

${ }^{2}$ Lecturer at the Faculty of Economics and Business, Sultan AgengTirtayasa University, hnnufus77@untirta.ac.id

${ }^{3}$ Lecturer at the Faculty of Economics and Business, Sultan AgengTirtayasa

University,lutfi.feb@untirta.ac.id
} 


\section{Introduction}

Company has a goal to realize growth and survival for the long term. In a global era marked by the same competition due to objectives and complex and high levels of acceleration, companies are required to have the ability to develop strategic choices in the field of marketing management so that they are able to adapt the dynamic environment (Teece et al., 1997). Therefore, markets must be managed through systematic efforts to place profits from superior market performance (Nerver and Slater, 1990). The marketing concept states that to achieve organizational goals such as market share and profitability depends on the company's ability to determine the needs and desires of the target market and satisfy it more effectively and efficiently compared to its competitors (Agarwal et al., 2003). Market orientation is a popular term used by practitioners in the field of marketing as an implementation of the marketing concept. More than four decades, market-oriented corporate strategy is seen by academics and practitioners as a main pillar to achieve superior company performance in both manufacturing and service companies (Salyova et al., 2015). Empirical studies aimed at analyzing marketing concepts and market orientation have been carried out more than forty years ago. Many academics and practitioners have been interested in writing literature related to market orientation (Kohli and Jaworski, 1990; Narver and Slater, 1990; Day, 1994; Han et al., 1998).

In recent years market orientation has increased and is seen as a key element in achieving company performance (Han et al., 1998). Market orientation is very important in modern marketing management (Narver and Slater, 1990). Marketoriented companies are considered to have higher market knowledge and have a better ability to deal with customers, this ability is seen as able to guarantee companies to obtain higher profits compared to companies that are less marketoriented (Day, 1994).

This research is motivated by the existence of research gaps the influence of market orientation on marketing performance. Several studies have proven that market orientation produces superior company performance (Ellis, 2006; Morgan et al., 2009; Kumar et al., 2011; Hussain et al., 2016). Several other studies give different results, namely market orientation has no effect on marketing performance (Selnes et al., 1996; Harris and Ogbonna, 2001; Gules et al., 2015). This research is motivated by the business phenomenon of the number of business units, the number of workers, the production volume and the sales volume of Brebes salted egg SMEs which have fluctuated (Table 1). Salted egg is a typical product of Brebes Regency which is famous for its deliciousness. In the Brebes Regency symbol, there is a picture symbol in the shape of an ovoid and an image symbol of onion. The picture symbol explains that salted eggs and onions are the specific product of Brebes Regency. The Brebes Regency Industry and Trade Investment Office (2020) states that salted eggs are one of the mainstay and flagship commodities as well as an icon of Brebes Regency. With the business phenomenon and research gap, the author bridges with the iconic product advantage. Iconic product advantage is the 
superiority of the company by making products that become icons or symbols that serve as a reminder for consumers with the symbols contained in these products (Hanfan, 2017).

Table 1. The Number of Business Units, Workers and Production Volume of Brebes Salted Egg SMEs

\begin{tabular}{|l|l|l|l|l|}
\hline Year & $\begin{array}{l}\text { Business } \\
\text { unit }\end{array}$ & $\begin{array}{l}\text { Labor } \\
\text { (person) }\end{array}$ & $\begin{array}{l}\text { Production Volume } \\
\text { (item) }\end{array}$ & $\begin{array}{l}\text { Sales Volume } \\
\text { (rupiah) }\end{array}$ \\
\hline 2011 & 27 & 92 & 4.987 .872 & 6.484 .233 \\
\hline 2012 & 35 & 117 & 3.072 .000 & 4.608 .000 \\
\hline 2013 & 39 & 133 & 3.672 .000 & 6.426 .000 \\
\hline 2014 & 52 & 160 & 4.420 .110 & 7.735 .193 \\
\hline 2015 & 52 & 160 & 4.420 .110 & 7.735 .193 \\
\hline 2016 & 30 & 63 & 6.882 .383 & 18.582 .434 \\
\hline 2017 & 52 & 160 & 5.000 .000 & 12.500 .000 \\
\hline 2018 & 134 & 335 & 8.040 .000 & 20.100 .000 \\
\hline 2019 & 134 & 335 & 8.040 .000 & 20.100 .000 \\
\hline
\end{tabular}

Source: Brebes Regency in Figures for 2011 - 2019.

\section{Methodology}

The research uses primary data, that is data obtained by interviews based on a list of questions to a number of respondents selected for this research. The research design used in this study is descriptive research. The questionnaire was processed and analyzed with AMOS 22.0. This research was conducted with a population of 150 salted egg SMEs in Brebes Regency, Indonesia. The samples used by 103 respondents, this samples meets the minimum standard sample criteria suggested by Hair et al. (2010). Table 2 shows the definition of variables and the types of indicators of each variable.

Table 2. Variable Definition and Indicator

\begin{tabular}{|l|l|l|}
\hline Variable & Definition & Indicator \\
\hline Market & $\begin{array}{l}\text { Strategically target customer targets } \\
\text { and build organizations that focus on } \\
\text { customer service, provide an inward - } \\
\text { focused competition base, provide } \\
\text { services that are in line with consumer } \\
\text { expectations, so that they win a } \\
\text { competition (Craven and Piercy, } \\
\text { 2015). }\end{array}$ & $\begin{array}{l}\text { X1: Consumer desires. } \\
\text { X3: Competition (Pelham, } \\
\text { 1997). }\end{array}$ \\
\hline $\begin{array}{l}\text { Product } \\
\text { Innovation }\end{array}$ & $\begin{array}{l}\text { The company's mechanism to adapt in } \\
\text { a dynamic environment, therefore } \\
\text { companies are required to be able to } \\
\text { create new thoughts, new ideas and } \\
\text { offer innovative products and service } \\
\text { improvements that satisfy customers } \\
\text { (Hurley and Hult, 1998). }\end{array}$ & $\begin{array}{l}\text { X4: New thoughts create } \\
\text { products. } \\
\text { Xexpertise in making } \\
\text { n6: Improducts. } \\
\text { satisfy customers (Hurley } \\
\text { and Hult, 1998). }\end{array}$ \\
\hline
\end{tabular}




\begin{tabular}{|l|l|l|}
\hline $\begin{array}{l}\text { Dynamic } \\
\text { Capability }\end{array}$ & $\begin{array}{l}\text { Capability to form, reform, configure, } \\
\text { and reconfigure company capabilities } \\
\text { so that they can respond to changes in } \\
\text { the environment well (Teece et al., } \\
1997) .\end{array}$ & $\begin{array}{l}\text { X7: Capability to form } \\
\text { products. } \\
\text { X8: Capability to reshape } \\
\text { the product. } \\
\text { X9: Capability to } \\
\text { configure the product } \\
\text { (Teece, et al., 1997). }\end{array}$ \\
\hline $\begin{array}{l}\text { Iconic Product } \\
\text { Advantage }\end{array}$ & $\begin{array}{l}\text { Superiority of the company by making } \\
\text { products that become icons or symbols } \\
\text { that serve as a reminder for consumers } \\
\text { with the symbols contained in these } \\
\text { products (Hanfan, 2017). }\end{array}$ & $\begin{array}{l}\text { X10: Superiority of salted } \\
\text { eggs as regional icons. } \\
\text { X11: Difference in the } \\
\text { taste of salted eggs. } \\
\text { X12: Salted egg types that } \\
\text { are difficult to imitate } \\
\text { (Hanfan, 2017). }\end{array}$ \\
\hline $\begin{array}{l}\text { Marketing } \\
\text { Performance }\end{array}$ & $\begin{array}{l}\text { A measure of achievement of overall } \\
\text { marketing process activities in the } \\
\text { company (Song and Parry, 1997). }\end{array}$ & $\begin{array}{l}\text { Xffectiveness. } \\
\text { X14: Sales growth. } \\
\text { X15: Profit growth (Song } \\
\text { and Parry, 1997). }\end{array}$ \\
\hline
\end{tabular}

Source: Data processed for this research.

Full model analysis can be seen in Figure 1:

Figure 1. Full Model Analysis

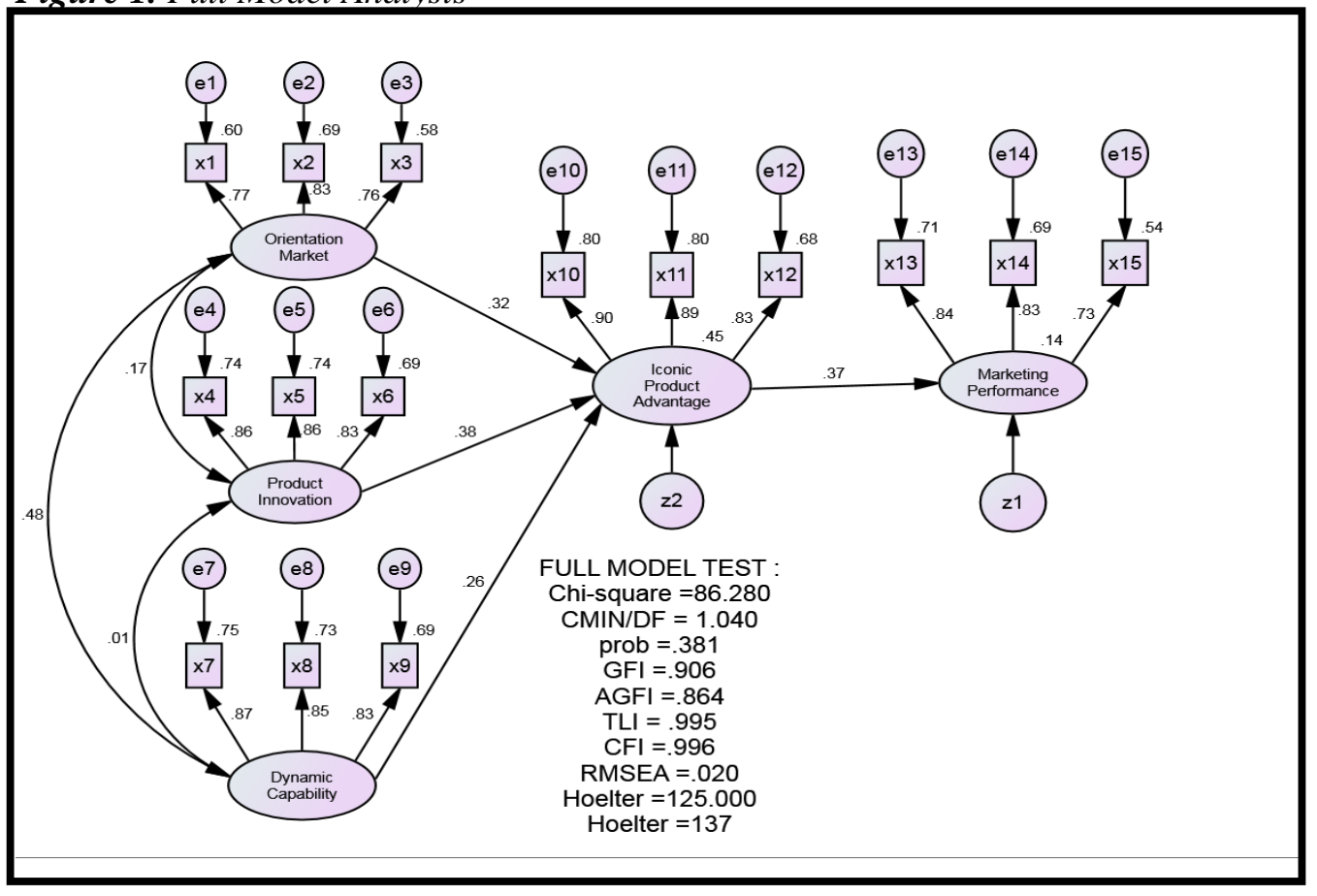

Source: Data processed for this research. 
The full model analysis produces for the goodness of fit Chi-Square value $=86.280$; $\mathrm{CMIN} / \mathrm{DF}=1.040 ;$ probability $=.381 ; \mathrm{RMSEA}=.020 ; \mathrm{GFI}=.906 ; \mathrm{AGFI}=.864$; $\mathrm{TLI}=.995 ; \mathrm{CFI}=.996$. Furthermore, the last goodness of fit statistic is critical $\mathrm{N}$ developed by Hoelter (1983). The critical analysis of N Hoelter's 0.05 and Hoelter's 0.01 , namely Hoelter's $0.05=125$; Hoelter's $0.01=137$ all of which met the fit criteria because the number of samples was 103 below the Hoelter's value as recommended by Hair et al. (2010). The analysis in Table 3 shows that the model suitability test produces a good level of acceptance.

Table 3. Goodness of Fit for the Full Model

\begin{tabular}{|l|l|l|l|}
\hline $\begin{array}{l}\text { Goodness of Fit } \\
\text { Index }\end{array}$ & Cut-Off Value & Analysis & Evalution \\
\hline Chi-Square & Expected to be small & 86.280 & Good \\
\hline CMIN/DF & $\leq 2.00$ & 1.040 & Good \\
\hline Probability & $\geq 0.05$ & .381 & Good \\
\hline RMSEA & $\leq 0.08$ & .020 & Good \\
\hline GFI & $\geq 0.90$ & .906 & Good \\
\hline AGFI & $\geq 0.90$ & .864 & Marginal \\
\hline TLI & $\geq 0.95$ & .995 & Good \\
\hline CFI & $\geq 0.95$ & .996 & Good \\
\hline Hoelter's 0,05 & $\leq 125$ & 103 & Good \\
\hline Hoelter's 0,01 & $\leq 137$ & 103 & Good \\
\hline
\end{tabular}

Source: Data processed for this research.

The loading factor significance test aims to evaluate whether an indicator used confirms that the indicator can together with other indicators explain a variable. The loading factor value required is must reach $\lambda \geq 0.50$ (Hair et al., 2010).

Table 4. Test of Loading Factor

\begin{tabular}{|l|l|}
\hline Variable & Value of Loading Factors \\
\hline Market Orientation & $\mathrm{X} 1: .773, \mathrm{X} 2: .830, \mathrm{X} 3: .761$ \\
\hline Product Innovation & $\mathrm{X} 4: .863, \mathrm{X} 5: .858, \mathrm{X} 6: .831$ \\
\hline Dynamic Capability & $\mathrm{X} 7: .869, \mathrm{X} 8: .852, \mathrm{X} 9: .831$ \\
\hline Iconic Product Advantage & $\mathrm{X} 10: .897, \mathrm{X} 11: .894, \mathrm{X} 12: .827$ \\
\hline Marketing Performance & $\mathrm{X} 13: .842, \mathrm{X} 14: .828, \mathrm{X} 15: .735$ \\
\hline
\end{tabular}

Source: Data processed for this research.

Table 4 shows that the value of the lambda coefficient ( $\lambda$ coefficient) or loading factors shows that all indicators have values above 0.5 ; because all criteria meet the requirements, then the model is worth testing. To find out the extent of the accuracy, and validity of a measuring instrument in research, validity is needed, while knowing the reliability of a research measuring instrument requires a high level of reliability. Testing the validity and reliability of the next variable is to calculate the construct reliability value and minimum extracted variance to state that accuracy and reliability have been reached at 0.50 . 
Table 5. Construct Reliability and Variance Extracted Full Model

\begin{tabular}{|c|c|c|c|c|c|}
\hline Indicator & Estimate & Squares Loading & Error & Construct Reliability & Variance Extract \\
\hline $\mathrm{X} 1$ & 0.773 & 0.597529 & 0.402471 & & \\
\hline $\mathrm{X} 2$ & 0.83 & 0.6889 & 0.3111 & & \\
\hline $\mathrm{X} 3$ & 0.761 & 0.579121 & 0.420879 & & \\
\hline Jumlah & 2.364 & 1.86555 & 1.13445 & 0.831257011 & 0.62185 \\
\hline $\mathrm{X} 4$ & 0.863 & 0.744769 & 0.255231 & & \\
\hline $\mathrm{X} 5$ & 0.858 & 0.736164 & 0.263836 & & \\
\hline $\mathrm{X} 6$ & 0.831 & 0.690561 & 0.309439 & & \\
\hline Jumlah & 2.552 & 2.171494 & 0.828506 & 0.887143128 & 0.723831333 \\
\hline $\mathrm{X} 7$ & 0.869 & 0.755161 & 0.244839 & & \\
\hline $\mathrm{X} 8$ & 0.852 & 0.725904 & 0.274096 & & \\
\hline $\mathrm{X} 9$ & 0.831 & 0.690561 & 0.309439 & & \\
\hline Jumlah & 2.552 & 2.171626 & 0.828374 & 0.887159079 & 0.723875333 \\
\hline $\mathrm{X} 10$ & 0.897 & 0.804609 & 0.195391 & & \\
\hline $\mathrm{X} 11$ & 0.894 & 0.799236 & 0.200764 & & \\
\hline $\mathrm{X} 12$ & 0.827 & 0.683929 & 0.316071 & & \\
\hline Jumlah & 2.618 & 2.287774 & 0.712226 & 0.905866788 & 0.762591333 \\
\hline $\mathrm{X} 13$ & 0.842 & 0.708964 & 0.291036 & & \\
\hline $\mathrm{X} 14$ & 0.828 & 0.685584 & 0.314416 & & \\
\hline $\mathrm{X} 15$ & 0.735 & 0.540225 & 0.459775 & & \\
\hline Jumlah & 2.405 & 1.934773 & 1.065227 & 0.844475426 & 0.644924333 \\
\hline
\end{tabular}

Source: Data processed for this research.

The results of the calculation of construct reliability values presented in Table 5 show that construct reliability and variance extracted have values above 0.5 . This shows that the indicators used have good validity and reliability to explain the variables.

\section{Development of Hypotheses}

\subsection{Effect of Market Orientation on Iconic Product Advantage}

Pranoto et al. (2019) examined the role of learning between organizations that contribute to transforming a green entrepreneurial orientation and market orientation towards increasing sustainable competitive advantage. There is a strong tendency that inter-organizational learning plays an important role as an intervening variable that operates by receiving input from green entrepreneurship orientation and market orientation, which acts as an exogenous construct. Therefore, greater interorganizational learning directs companies to achieve greater sustainable competitive advantage. Maruta et al. (2017), who analyzed the effects of market orientation, entrepreneurial orientation, and imitation strategy on the competitive advantage of leather bag and luggage SMEs in East Java, showed that market orientation, entrepreneurial orientation, and imitation strategy had a positive and significant impact to the competitive advantage of UKM leather bags and luggage in East Java. The higher the market orientation, the stronger the entrepreneurial orientation, and 
the better the imitation strategy. Thus the competitive advantage of UKM leather bags and luggage in East Java is also higher. Therefore the research hypothesis is:

\section{H1: Market orientation influences the iconic product advantage.}

\subsection{Effect of Product Innovation to Iconic Product Advantage}

Using a sample of 74 high-performance businesses in Costa Rica, Lafuente et al. (2018) used fuzzy analysis (qualitative comparative analysis) to evaluate how the development of sustainable and traditional product innovation strategies was conditioned by business learning abilities and entrepreneurial orientation in knowledge-business intensive (KIBS) and non-knowledge intensive business. KIBS companies are found to improve knowledge and customer-oriented orientations that characterize their businesses and contribute short-term work to improve the personal service characteristics needed to achieve optimal traditional and sustainable product innovation. Kuncoro and Suriani (2017) also found the effect of product innovation on sustainable competitive advantage in rabbit meat traders in NgablakMagelang Regency. Therefore the research hypothesis is as follows:

\section{H2: Product innovation influences the iconic product advantage.}

\subsection{Effect of Dynamic Capability to Iconic Product Advantage}

Research by Naguib et al. (2017) examined the relationship between dynamic capabilities (experience, routine, skills, company characteristics, knowledge and technology) and the sustainability of competitive advantage in the Egyptian pharmaceutical sector. The results of the study support the idea that there is a significant relationship between four of the six dynamic capabilities (experience, skills, characteristics and knowledge of the company) and the sustainability of competitive advantage for pharmaceutical companies in Egypt. This research helps pharmaceutical companies in Egypt properly direct their investments and determine weaknesses in their dynamic capabilities that need to be addressed. Banerjee et al. (2018) who reviewed the evolution of the dynamic capability approach from a resource-based view over many years and how it is suitable for companies to survive in a dynamically changing environment. It also draws attention to how resources and capabilities in the internal environment help build dynamic capabilities and their component factors and help create competitive advantage. The development of these resources and capabilities is important for companies to overcome challenging external environments and lead to competitive advantage. The competitive advantage created by the company for itself is the foundation for organizational performance and has a significant relationship with it. Therefore the research hypothesis is:

\section{H3: Dynamic capability influences the iconic product advantage.}




\subsection{Effect of Iconic Product Advantage to Marketing Performance}

Organizations are now turning to many standard techniques for achieving competitive advantage, and if they are sustainable, the organization benefits from competitive advantage. When the market grows more saturated, only organizations with the highest sustainable competitive advantage benefit the most. Elijah and Millicent (2018) confirm that the effects of corporate strategy, resource and competitive environment and human resource strategy on sustainable competitive advantage cannot be denied and they have many impacts on company performance.

Potjanajaruwit (2018) who studies the factors that cause technological capabilities and collaboration between organizations that influence the competitive advantage of startups in Thailand. The sample used in this study consisted of entrepreneurs and startup executives in Thailand selected by using the stratified random sampling method. The results found that the factors that cause technological capabilities and collaboration between organizations have a direct positive effect on startup competitive advantage, and competitive advantage has a direct positive effect on startup performance in Thailand. In addition, it is clear that technological capabilities and collaboration between organizations have a direct effect on startup performance in Thailand, where all previous effects are statistically significant. Therefore the research hypothesis is:

H4: Iconic product advantage influences the marketing performance.

\section{Conclusion and Recommendations}

After being analyzed and processed with analytical tools, the following hypotheses have been proved (Table 6):

Table 6. Testing Hypotheses

\begin{tabular}{|l|l|l|l|l|l|l|l|}
\hline \multicolumn{2}{|l|}{ Variable Relationship } & $\begin{array}{l}\text { Estima } \\
\text { te }\end{array}$ & S.E. & C.R & P & Conclusion \\
\hline $\begin{array}{l}\text { Iconic Product } \\
\text { Advantage }\end{array}$ & $<--$ & $\begin{array}{l}\text { Orientation } \\
\text { Market }\end{array}$ & .441 & .155 & 2.838 & .005 & $\begin{array}{l}\text { H1 } \\
\text { Accepted }\end{array}$ \\
\hline $\begin{array}{l}\text { Iconic Product } \\
\text { Advantage }\end{array}$ & $<--$ & $\begin{array}{l}\text { Product } \\
\text { Innovation }\end{array}$ & .433 & .106 & 4.101 & $* * *$ & $\begin{array}{l}\text { H2 } \\
\text { Accepted }\end{array}$ \\
\hline $\begin{array}{l}\text { Iconic Product } \\
\text { Advantage }\end{array}$ & $<--$ & $\begin{array}{l}\text { Dynamic } \\
\text { Capability }\end{array}$ & .283 & .116 & 2.445 & .015 & $\begin{array}{l}\text { H3 } \\
\text { Accepted }\end{array}$ \\
\hline $\begin{array}{l}\text { Marketing } \\
\text { Performance }\end{array}$ & $<--$ & $\begin{array}{l}\text { Iconic } \\
\text { Product } \\
\text { Advantage }\end{array}$ & .332 & .098 & 3.390 & $* * *$ & $\begin{array}{l}\text { H4 } \\
\text { Accepted }\end{array}$ \\
\hline
\end{tabular}

Source: Data processed for this research.

The hypothesis testing concluded that $\mathrm{H} 1$ was accepted, with a value of $\mathrm{CR}=2.838$ $\geq 1.96$ with a probability value $=.005$. $\mathrm{H} 2$ is accepted, with a value of $\mathrm{CR}=4.101 \geq$ 
1.96 with a probability value $=.000 . \mathrm{H} 3$ is accepted, with a value of $\mathrm{CR}=2,445 \geq$ 1,96 with a probability value $=.015$. $\mathrm{H} 4$ is accepted with a value of $\mathrm{CR}=3.390 \geq$ 1.96 with a probability value $=.000($ Table 6$)$.

Managerial implications arising from this research are that salted egg SMEs must strategically set consumer targets and build an organization that focuses on customer service, provides an inward-focused competition base, provides services that are in line with consumers' expectations, so that they can win in competition. SMEs must be able to adapt the dynamic environment, therefore companies are required to be able to create new thoughts, new ideas and offer innovative products and improved services that satisfy customers. SMEs must also be able to shape products, reshape products, configure products, and reconfigure products so that they can deal with environmental changes well. The superiority of SMEs in making products that are icons or symbols that serve as a reminder for consumers with the symbols contained in these products must also be increased so that the bias can improve their marketing performance.

The practical implications resulting from this research are the iconic product advantage influenced by market orientation, product innovation and dynamic capability by $44.9 \%$. While marketing performance is influenced by market orientation, product innovation, dynamic capability and iconic product advantage of $13.6 \%$. So that the iconic product advantage can be maximally increased by SMEs, it must pay attention to market orientation, product innovation and dynamic capability. Furthermore, SME marketing performance can increase to the maximum by paying attention to market orientation, product innovation, dynamic capability and iconic product advantage.

\section{References:}

Agarwal, S., Erramilli, M.K., Dev, C.S. 2003. Market orientation and performance in service firms: Role of innovation. The Journal of Services Marketing, 17(1).

Banerjee, C.S., Farooq, A., Upadhyaya, S. 2018. The Relationship between Dynamic Capabilities, Competitive Advantage \& Organizational Performance. International Journal of Interdisciplinary Research and Innovations, 6(3), 603-610.

Brebes Regency Industry and Trade Investment Office. 2020.

Craven, D.W. and Piercy, N.F. 2015. Strategic Marketing. New York, McGraw-Hill.

Day, G.S. 1994. The capabilities of market-driven organizations. Journal of Marketing, 58(37).

Elijah, A.B., Millicent, A.D. 2018. The Impact of a Sustainable Competitive Advantage on a Firm's Performance: Empirical Evidence from Coca-Cola Ghana Limited. Global Journal of Human Resource Management, 6(5), 30-46.

Ellis, P.D. 2006. Market orientation and performance: A meta-analysis and cross-national comparisons. Journal of Management Studies, 43(5), 1089-1107.

Gules, H.K., Zerenler, M., Cagliyan, V., Sener, T., Karaboga, K. 2015. The Effect of Market Orientation and Innovation Ability on Enterprise Performance: A Practice 
of Structural Equation Modelling Analysis: A Research on SMES. European Scientific Journal, 11(10), 31-42.

Hair, J.F., Black, W.C., Babin, B.J., Anderson, R.E. 2010. Multivariate Data Analysis, edited by P.P. Hall.

Han, J.K., Kim, N., Srivastava, R.K. 1998. Market Orientation and Organizational Performance: Is Innovation a Missing Link? Journal of Marketing, 62, 30-45.

Hanfan, A. 2017. Building Iconic Product Advantage to Improve MSMEs Marketing Performance. DeReMa Jurnal Manajemen, 12(2), 162-186.

Harris, L.C., Ogbonn, E. 2001. Strategic human resource management, market orientation, and organizational performance. Journal of Business Research, 51, 157-166.

Hoelter, J.W. 1983. The analysis of covariance structures: Goodness-of-fit indices. Sociological Methods and Research, (11), 325-344.

Hurley, R.F., Hult, G.T.M. 1998. Innovation, Market Orientation, and Organizational Learning: An Integration and Empirical Examination. Journal of Marketing 62(3), 42-54.

Hussain, J., Shah, F.A., Akhtar, C.S. 2016. Market Orientation and Organizational Performance in Small and Medium Sized Enterprises a Conceptual Approach. City University Research Journal, 06(01), 166-180.

Kohli, A.K., Jaworski, B.J. 1990. Market Orientation: The Construct, Research Propositions, and Managerial Implications. Joumal of Marketing, (54), 1-18.

Kumar, V., Jones, E., Venkatesan, R., Leone, R.P. 2011. Is Market Orientation a Source of Sustainable Competitive Advantage or Simply the Cost of Competing? Journal of Marketing, 75, 16-30.

Kuncoro, W., Suriani, W.O. 2017. Achieving sustainable competitive advantage through product innovation and market driving. Asia Pacific Management Review, 1-7.

Lafuente, E., Vaillant, Y., Leiva, J.C. 2018. Sustainable and Traditional Product Innovation without Scale and Experience, but Only for KIBS! Sustainability, 10(1169), 1-18.

Maruta, A.I.G.N., Sularso, R.A., Susanti, N. 2017. The Effect of Market Orientation, Entrepreneurship Orientation, and Imitation Strategy on Competitive Advantage (Study on SME of Leather Bag and Suitcase in East Java). International Journal of Business and Management Invention, 6(7), 24-35.

Morgan, N.A., Vorhies, D.W., Mason, C.H. 2009. Market Orientation, Marketing Capabilities, and Firm Performance. Strategic Management Journal, (30), 909-920.

Naguib, A.N., Elsaid, E., Elsaid, A.M. 2017. The Impact of Dynamic Capabilities on Sustainable Competitive Advantage in the Pharmaceutical Sector in Egypt. Business and Management Research, 6(2), 1-17.

Narver, J.C., Slater, S.F. 1990. The Effect of a Market Orientation on Business Profitability. Journal of Marketing, 54(4), 20-35.

Pelham, A.M. 1997. Mediating influences on the relationship between market orientation and profitability in small industrial firms. Journal of Marketing Theory and Practice, 5(3), 55-65.

Potjanajaruwit, P. 2018. Competitive advantage effects on firm performance: A Case study of startups in Thailand. Journal of International Studies, 10(1), 104-111.

Pratono, A.H., Darmasetiawan, N.K., Yudiarso, A., Jeong, B.G. 2019. Achieving sustainable competitive advantage through green entrepreneurial orientation and market orientation: The role of inter-organizational learning. Emerald Publishing Limited, $1-15$. 
Salyova, S., Petrovicova, J.T., Nedelova, G., Dado, J. 2015. Effect of Marketing Orientation on Business Performance: A Study from Slovak Foodstuff Industry. Procedia Economics and Finance, 34, 622-629.

Selnes, F., Jaworski, B.J., Kohli, A.K. 1996. Market orientation in United States and Scandinavian companies: a cross-cultural view. Scand J Manage, 12(2), 139-157.

Song, X.M., Parry, M.E. 1997. A cross-national comparative study of new product development processes: Japan and the United States. Journal of Marketing, 61(2).

Teece, D.J., Pisano, G., Shuen, A. 1997. Dynamic Capabilities and Strategic Management. Strategic Management Journal, 18(7), 509-533. 